\title{
Trans-Atlantic Distribution of a Mangrove Oyster Species Revealed by 16S mtDNA and Karyological Analyses
}

\author{
S. LAPÈGUE ${ }^{1, *}$, I. BOUTET ${ }^{1,2, \dagger}$, A. LEITÃO ${ }^{3}$, S. HEURTEBISE ${ }^{1}$, P. GARCIA ${ }^{2}$, \\ C. THIRIOT-QUIÉVREUX ${ }^{3}$, AND P. BOUDRY ${ }^{1}$ \\ ${ }^{1}$ IFREMER, Laboratoire de Génétique et Pathologie, B.P. 133, 17390 La Tremblade, France; \\ ${ }^{2}$ Laboratoire de Biologie et Environnement Marins, Institut de la Mer et du Littoral, \\ Avenue Lazaret, Port des Minimes, 17000 La Rochelle, France; and ${ }^{3}$ Observatoire. \\ Océanologique, UPMC-CNRS-INSU, B.P. 28, 06230 Villefranche-sur-mer, France
}

\begin{abstract}
Three species of mangrove oysters, Crassostrea rhizophorae, C. brasiliana, and $C$. gasar, have been described along the Atlantic shores of South America and Africa. Because the distribution of these molluscs is of great biological and commercial interest, their taxonomy and distribution deserve further clarification. Therefore, 15 populations were sampled from both continents. Their $16 \mathrm{~S}$ mitochondrial polymorphism was studied by sequencing and PCR-RFLP analysis. Two haplotypes were identified. Haplotype a was the only one observed in Africa, but it was also observed in South America together with haplotype b. Because $C$. gasar is the only mangrove oyster identified on the west coast of Africa, haplotype a was attributed to this species, which has thus been shown to occur in South America. Haplotype b is attributed to $C$. rhizophorae. The karyotypes of specimens of $C$. gasar, from Africa and from South America, were very similar, and both species were observed at the same location in Brazil. The occurrence of C. gasar in South America adds a third species - in addition to $C$. rhizophorae and C. brasiliana-to the list of species present along these coasts. The predominant surface circulation patterns in this part of the Atlantic Ocean favor the hypothesis that $C$. gasar was transported from Africa to America. Finally, a phylogenetic tree built with seven $16 \mathrm{~S}$
\end{abstract}

Received 30 May 2001; accepted 3 April 2002.

* To whom correspondence should be addressed. E-mail: slapegue@ ifremer.fr

$\dagger$ Current address: Laboratoire des Sciences de l'Environnement Marin (LEMAR), UMR CNRS 6539, Institut Universitaire Européen de la Mer, Université de Bretagne Occidentale, 29280 Plouzané, France. sequences from Crassostrea and Saccostrea species showed that C. gasar is intermediate between the American Crassostrea species (C. virginica and C. rhizophorae) and the Asian species (C. gigas and C. ariakensis).

\section{Introduction}

Mangrove ecosystems are widely distributed; they cover $100,000-200,000 \mathrm{~km}^{2}$ of the world's tropical estuarine zones where sea and rivers mix (Blasco et al., 1998). The mangrove trees characterize these ecosystems and constitute a natural habitat for mangrove oysters; the aerial prop roots of the trees provide the oyster larvae with a convenient place to settle in the intertidal zone. Because mangrove oysters live naturally on mangrove roots, which are called rhizophores, the latter term was used in the taxonomic name of a South American mangrove oyster, Crassostrea rhizophorae (Guilding, 1828). In fact, numerous species of mangrove oysters have been described, all in the genus Crassostrea; but the taxonomic identification is difficult and uncertain, so their geographical ranges are also often poorly known.

These problems and uncertainties are well illustrated by the mangrove oysters of South America and Africa. The taxonomic status of the oysters growing along the Atlantic coast of South America has been widely investigated morphologically, ecologically, physiologically, and genetically. Some authors have regarded the subtidal rocky shore form of $C$. rhizophorae (Guilding, 1828) as distinct, mainly because of its large size (e.g., Nascimento, 1991), and have applied to it the binomen $C$. brasiliana (Lamarck, 1819). 
But because size is considered unreliable as a taxonomic character, C. brasiliana was held by Rios (1994) to be synonymous with the generally smaller $C$. rhizophorae. However, large differences in growth rates and larval morphology have been described between $C$. rhizophorae and C. brasiliana populations, suggesting that they may indeed be distinct biological species (Absher, 1989). Moreover, their geographic range appears to be different: $C$. brasiliana occurs on the Caribbean coast of South America, whereas C. rhizophorae is more common and is found from Florida to Brazil (Littlewood, 1991). Finally, the occurrence of two distinct species along the South American coasts was clearly demonstrated recently by an allozyme study (Ignacio et al., 2000). C. rhizophorae is now extensively cultivated throughout the various countries of the Caribbean Sea, as well as in the West Indies, and is considered to be a commercially important species (Arakawa, 1990). Moreover, $C$. rhizophorae is also being produced in New Guinea (FAO, 1999).

Oysters from the coasts of Africa have been less extensively studied than those from South America (Marozova et al., 1991). Although C. cucculatta (Born) is the only species described from the eastern coast of Africa (and Madagascar), two species names are used for oysters growing along the western coast: $C$. gasar (Adanson) and C. tulipa (Lamarck). C. gasar has been reported in Mauritania (Gowthorpe, 1993), Senegal and Gambia (Diop, 1993), Ivory Coast (Egnankou, 1993), Nigeria (Isebor and Et Awosika, 1993), and Cameroon (Zogning, 1993). Two different names were given in Togo: "Gryphea" or C. gasar (Akpagana, 1993); and in Congo: Gryphea gasar (Crassostrea tulipa, Lamarck) (Makaya, 1993). The C. tulipa species name is also mentioned in Liberia (Yoo and Ryu, 1984) and in Sierra Leone (Kamara, 1982). As C. tulipa is now considered a synonym of $C$. gasar (Marozova et al., 1991), we will use this name for samples collected from the south Atlantic African coast. C. gasar is a commercially important bivalve in Africa (Nicklès, 1950)-for example, in Nigeria (Ajana, 1979) and Senegal (Cormier-Salem, 1987)-and its potential for more intensive aquacultural production has been studied (Cormier-Salem, 1987; Marozova et al., 1991).

A typical feature of oysters from the genus Crassostrea is the extreme variability of the shell (Galtsoff, 1964). Moreover, this variability also extends to the soft tissues (Lawrence, 1995). Therefore, oysters are often difficult to differentiate on the basis of their morphology. Consequently, other methods, such as karyological and molecular analyses, must be applied to distinguish the different mangrove oyster species. A study of seven species of cupped oyster showed that the karyotype of $C$. gasar is clearly isolated from two other groups, one composed of $C$. gigas, $C$. angulata, and $C$. sikamea, and the other of $C$. virginica, $C$. ariakensis, and Saccostrea commercialis (Leitão et al., 1999). The karyo- type of $C$. rhizophorae has also been previously reported in specimens from Mexico (Rodriguez-Romero et al., 1979; Ladron de Guevara et al., 1996) and from Venezuela (Marquez, 1992), and it appears to be different from those of the species described by Leitão et al. (1999).

Molecular methods can usefully complement morphological and karyological studies in determining the status of oyster taxa. For example, such methods have already been used to infer the phylogenetic relationships among species of cupped oysters (Littlewood, 1994), to discriminate between closely related Asian Crassostrea species (Banks et al., 1993; Hedgecock et al., 1999), to better understand the close relationship between $C$. gigas and $C$. angulata (Boudry et al., 1998; O'Foighil et al., 1998), and to distinguish among sympatric species of the rock oyster Saccostrea in Thailand (Day et al., 2000). However, little molecular taxonomy has been done on mangrove oysters: a few genetic studies (allozyme data) have been carried out on C. rhizophorae (Hedgecock and Okazaki, 1984; Ignacio et al., 2000), but nothing has been published previously about C. gasar.

In this study, the methods of molecular biology and karyology were used to ascertain the taxonomic status of the mangrove species present along the shores of the south Atlantic, and to determine the phylogenetic position of the African species in the Crassostrea clade. To these ends, we studied African mangrove oyster samples, described as $C$. gasar or C. rhizophorae (W.B. Dambo, Rivers State University of Science and Technology, Nigeria, pers. comm.), and American mangrove oysters, presumed to be $C$. rhizophorae or C. brasiliana. In particular, we analyzed the $16 \mathrm{~S}$ mitochondrial fragment that had already been studied in other species of the genus Crassostrea by O'Foighil et al. (1995), and also in Saccostrea (K.K.Y. Lam and B. Morton, Swire Institute of Marine Science, The University of Hong Kong, China, unpubl. data) and Ostrea (Jozefowicz and O'Foighil, 1998). With these data, we could analyze the genetic relationship between $C$. gasar and the other species. We also examined the karyotype of the presumed $C$. rhizophorae samples from French Guiana and compared them with the karyotype of $C$. gasar from Senegal.

\section{Materials and Methods}

\section{Sampling}

Ethanol-fixed samples or live mangrove oysters were obtained from wild populations of south Atlantic coasts (see Fig. 1 for locations). Putative C. rhizophorae were collected along the Atlantic coast of South America: from Martinique in 1997 (MAS), French Guiana in 1997 (SIN), and Brazil. From this last location, two samplings were made, the first in 1997 (PAR1) on two islands (Ilha Rosa and Ilha das Gambas) inside Paranagua Bay, and the second sampling in 1998 at the harbor of Guaraqueçaba on the border of the 


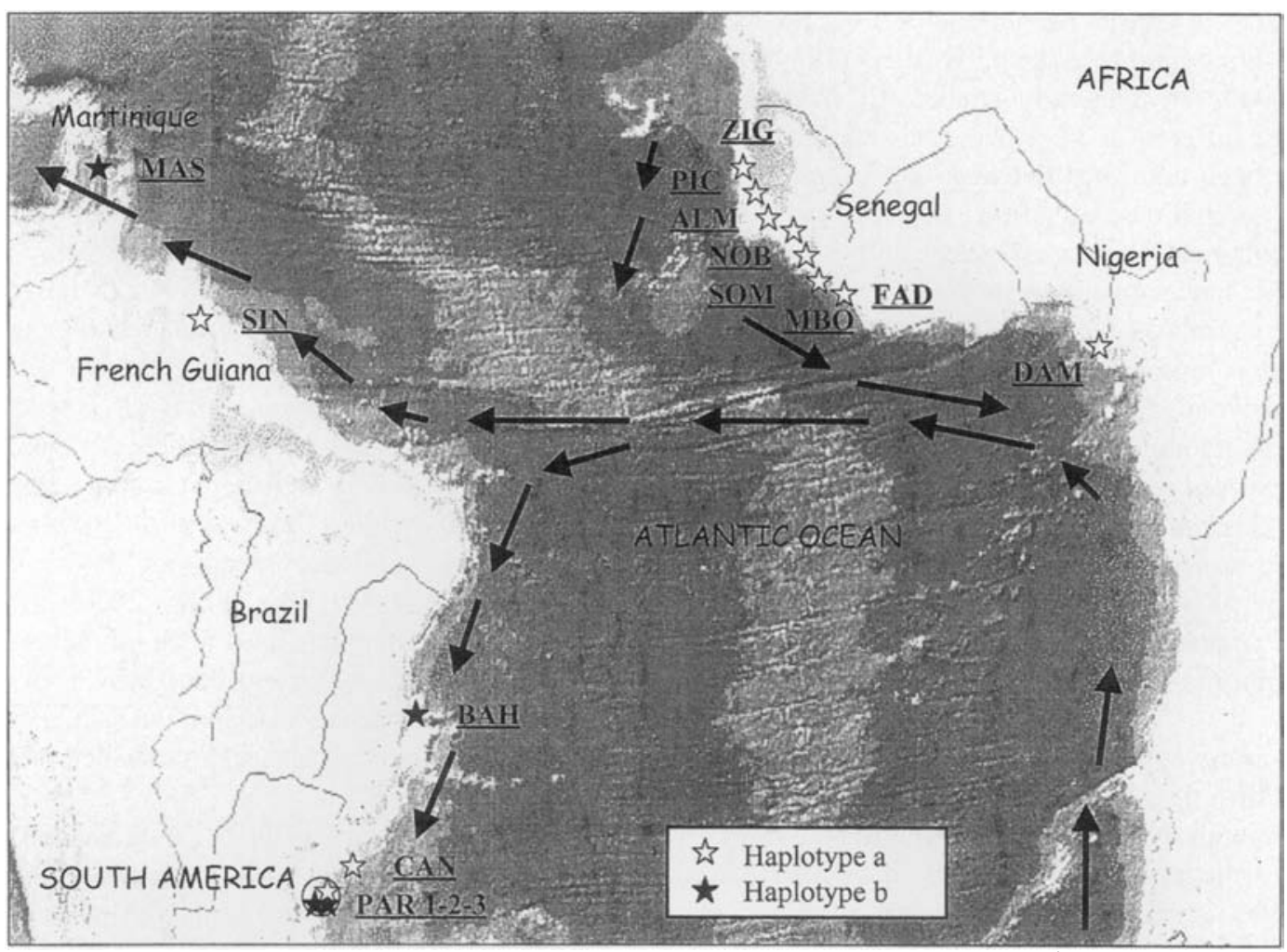

Figure 1. Population collection sites and their taxonomic status based on $16 \mathrm{~S}$ gene analysis. The arrows indicate the predominant surface circulation patterns in this part of the Atlantic Ocean. See legend of Table 1 for details on the three PAR samples.

same bay. In this second sample, two groups (PAR2 and PAR3) were selected on the basis of their size: PAR2 specimens described as "fast growers," and PAR3 specimens described as "slow growers." Two other samples from Brazil were collected in 1999: in the Cananéia Bay (CAN), and near Salvador do Bahia (BAH). Putative C. gasar samples were provided in 1999 from locations along the Senegalese coasts (ZIG, NOB, PIC, ALM, SOM, MBO, FAD), and specimens were taken from the Niger estuary (DAM), described as C. rhizophorae in Nigeria in 2000. Generally, the samples were collected on either mangrove roots or rocks; but in the Paraguana Bay, they were all sampled on rocks, and in French Guiana on mangrove roots. Table 1 summarizes the characteristics of these samples. Two animals from each of the populations SIN and NOB were chosen for karyological analysis, as they were initially thought to represent $C$. rhizophorae and $C$. gasar respectively.

\section{Mitochondrial DNA analysis}

DNA extraction of gill fragments was performed either by a Chelex-based method, as described in Estoup et al. (1996), or by a phenol/chloroform method, as described by Moore (1993). We amplified the $16 \mathrm{~S}$ mitochondrial frag- ment (16SrDNA: the large subunit rRNA-coding gene) with primers described by Banks et al. (1993), according to the protocol detailed in Boudry et al. (1998).

A first set of samples (two individuals from each of nine populations, as indicated in Table 1) was studied by sequencing the mitochondrial $16 \mathrm{~S}$ fragment. The PCR products were then purified with a high pure PCR product purification kit (Boehringer-Mannheim, Germany), and manually sequenced with an oligonucleotide tailing kit (Boehringer-Mannheim, Germany) and $\gamma 33 \mathrm{P}$ radiolabeled deoxynucleotide triphosphate (dNTP). The sequencing reaction, consisting of 35 cycles $\left(30 \mathrm{~s}, 95^{\circ} \mathrm{C}\right.$, denaturating; $30 \mathrm{~s}, 55^{\circ} \mathrm{C}$, annealing; $1 \mathrm{~min}, 72^{\circ} \mathrm{C}$, elongation), was performed according to the manufacturer's instructions.

The samples sequences-together with some sequences already obtained for $C$. virginica, $C$. gigas, $C$. ariakensis (O' Foighil et al., 1995), S. commercialis and S. mordax (K.K.Y. Lam and B. Morton, Swire Institute of Marine Science, The University of Hong Kong, China, unpubl. data, accession numbers AF353099 AF353100), and $O$. edulis (Jozefowicz and O'Foighil, 1998)-were aligned with the software CLUSTALW (Thompson et al., 1994). Parsimony analysis was implemented with PHYLIP (Felsenstein, 1989) using the program DNAPARS. Boot- 
Table 1

Characteristics of the populations of Crassostrea sampled

\begin{tabular}{|c|c|c|c|c|c|}
\hline Population name & Putative species & Location & $\begin{array}{l}\text { Number of } \\
\text { individuals }\end{array}$ & $\begin{array}{c}\text { DNA } \\
\text { sequence }\end{array}$ & $\begin{array}{c}\text { PCR-RFLP } \\
\text { haplotype }\end{array}$ \\
\hline $\mathrm{ZIG}$ & C. gasar & Zinguichor, Senegal & 2 & $\mathrm{~A}$ & a \\
\hline NOB & C. gasar & Kafountine, Senegal & 2 & A & a \\
\hline $\mathrm{PIC}$ & C. gasar & Senegal & 2 & A & a \\
\hline ALM & C. gasar & Almadies, Senegal & 2 & A & a \\
\hline SOM & C. gasar & Somone, Senegal & 12 & & a \\
\hline MBO & C. gasar & M'Bour, Senegal & 6 & & a \\
\hline FAD & C. gasar & Joal, Senegal & 6 & & a \\
\hline DAM & C. rhizophorae & Niger estuary, Nigeria & 12 & & a \\
\hline SIN & C. rhizophorae & Mont Sinery, French Guiana & 2 & A & a \\
\hline MAS & C. rhizophorae & Martinique & 2 & $\mathrm{~B}$ & $b$ \\
\hline PAR1* & C. rhizophorae & Paranagua Bay, Brazil & 2 & A & a \\
\hline PAR2* & C. rhizophorae & Paranagua Bay, Brazil & 2 & $\mathrm{~B}$ & $\mathrm{~b}$ \\
\hline PAR3* & C. rhizophorae & Paranagua Bay, Brazil & 2 & $\mathrm{~B}$ & $b$ \\
\hline $\mathrm{BAH}$ & C. rhizophorae & Salvador do Bahia, Brazil & 6 & & $\mathrm{~b}$ \\
\hline CAN & C. rhizophorae or C. brasiliana & Cananéia & 6 & & a \\
\hline
\end{tabular}

* The three samples PAR were collected in the same area, the Paranagua Bay in Brazil. However, PAR1 was collected in 1997 on two islands inside the bay, and PAR2 and PAR3 in 1998 in a harbor on the border on the bay. Furthermore, the latest two samples differ in size. See Figure 1 for the location of the samples.

strap analysis with 100 replicates was performed by the SEQBOOT and CONSENSE programs from the PHYLIP package. Pairwise sequence divergences between species were estimated by the DNADIST program from PHYLIP according to Kimura's two-parameter model (Kimura, 1980).

With a second set of samples, the same mitochondrial fragment was studied by PCR-RFLP using the appropriate TaqI restriction enzyme at $65^{\circ} \mathrm{C}$; the particular enzyme selected was determined by the sequence information we obtained. Restriction reactions were performed in a $20-\mu l$ volume composed of PCR product, $1 \times$ reaction buffer, and 2-5 units of endonuclease for $2 \mathrm{~h}$. The digested results were resolved after electrophoresis on $1 \%$ agarose gels in $1 \times$ TBE (Tris-boric acid-EDTA), and stained with ethidium bromide.

\section{Karyological analysis}

Chromosome preparations were carried out according to Leitão et al. (1999). After acclimation in the hatchery of La Tremblade, France, oysters were incubated in a solution of colchicine $(0.005 \%)$ in seawater. Dissected gills were treated in sodium citrate $(0.9 \%)$, and then fixed in four successive baths of a freshly prepared mixture of absolute ethanol and acetic acid (3:1). Slides were prepared by an air-drying technique (Thiriot-Quiévreux and Ayraud, 1982) and finally stained with Giemsa $4 \%, \mathrm{pH} 6.8$. Ten metaphases from each supposed species were selected, and karyotypes were constructed. Chromosome measurements were then performed with a digitizer tablet (Summa Sketch
II) interfaced with a Macintosh computer. Data analysis was performed with an Excel (Microsoft) macro program. Terminology relating to centromere position follows that of Levan et al. (1964) and takes into account the confidence limits of the centromeric index means. Nucleolus organizer regions (NORs) were silver-stained directly on unstained slides using the technique of Howell and Black (1982).

\section{Results}

\section{Mitochondrial DNA sequence analysis}

A PCR fragment of 570 base-pairs from the $16 \mathrm{~S}$ mitochondrial ribosomal gene was obtained and sequenced for 18 individuals from nine South American and African Atlantic coast samples of mangrove oysters (Table 1). Only two different sequences were obtained; they are denoted by capital letters A and B in Table 1. These were registered in the DDBJ/EMBL/GenBank databases under accession numbers AJ312937 and AJ312938. These two sequences differ in length ( 473 and 465 bases-pairs) due to 14 insertion or deletion sites. In addition, 45 substitution sites ( 30 transitions and 15 transversions) were observed. Their divergence, based on Kimura's two-parameter model, was $11.34 \%$ (Table 2).

The alignment in Figure 2 is the result of comparing mitochondrial $16 \mathrm{~S}$ sequences $\mathrm{A}$ and $\mathrm{B}$ with those obtained for $C$. gigas, $C$. virginica, and $C$. ariakensis by O'Foighil et al. (1995), and those obtained for S. mordax, S. commercialis (accession numbers AF353099 and AF353100), and $O$. edulis by Jozefowicz and O'Foighil (1998); O. edulis 
Table 2

Pairwise sequence divergences, according to Kimura's two-parameter model (Kimura, 1980), among the seven species studied for the 480 nucleotide mt 165 rDNA fragment

\begin{tabular}{|c|c|c|c|c|c|c|c|}
\hline 1. Sequence A (C. gasar) & 0 & & & & & & \\
\hline 3. C. virginica & 0.1288 & 0.0357 & 0 & & & & \\
\hline 4. C. gigas & 0.1772 & 0.1653 & 0.1657 & 0 & & & \\
\hline 5. C. ariakensis & 0.1805 & 0.1923 & 0.1835 & 0.0575 & 0 & & \\
\hline 8. O. edulis & 0.2314 & 0.2126 & 0.2028 & 0.1823 & 0.1706 & 0.1575 & 0.1716 \\
\hline
\end{tabular}

O. edulis serves as an outgroup. Two pairwise comparisons yielding low genetic distance estimates are presented in boldface. Species in parentheses are those associated to the sequences described in this report.

* Genera: C., Crassostrea; S., Saccostrea; O., Ostrea.

was considered as an outgroup. The sequence divergences are given in Table 2. Apart from the $O$. edulis outgroup, four groups of sequences can clearly be distinguished on the tree presented in Figure 3: (1) C. gigas and C. ariakensis, (2) C. virginica and sequence B, (3) S. mordax and S. commercialis, and (4) sequence $\mathrm{A}$. The first three groups are congruent with the three clades of cupped oysters described in O'Foighil and Taylor (2000). Inside the first two groups, divergence is relatively low: $5.75 \%$ between $C$. gigas and $C$. ariakensis, and $3.57 \%$ between $C$. virginica and sequence B. Inside the Saccostrea group, the divergence is higher: $10.21 \%$ between $S$. mordax and $S$. commercialis. In this context, sequence $\mathrm{A}$-which displays an $11 \%$ divergence with the American Crassostrea oysters (group 2), and 17\% with the Asian Crassostrea oysters (group 1)-can be considered as closer to the American Crassostrea oysters. However, whether sequence $A$ is intermediate between the Asian and American Crassostrea oysters, or falls within the American Crassostrea oysters, is difficult to determine.

\section{Geographic distribution of PCR-RFLP haplotypes}

In the PCR-RFLP analysis, using the TaqI endonuclease, the two haplotypes (denoted by lower-case letters $a$ and $b$, corresponding to the sequences $\mathrm{A}$ and $\mathrm{B}$, respectively) were rapidly identified. Haplotype $b$ was found only on the South American coast, whereas haplotype a was found on both the African and South American coasts: in French Guiana (SIN) and in two locations in Brazil (PAR1 and CAN) (Table 1, Fig. 1). All locations were monomorphic for one or the other haplotype, but both haplotypes were found within Paranagua Bay among samples PAR1, PAR2, and PAR3.

\section{Karyological analysis}

A diploid complement of 20 chromosomes, which is commonly observed in oysters (Nakamura, 1985), was con- firmed in the samples. Means of the relative chromosome length and centromeric indexes (Table 3) are given for the individuals from Senegal (sample NOB), presumed to be $C$. gasar, and French Guiana (sample SIN), initially identified as $C$. rhizophorae. The African oyster presented a karyotype (Fig. 4A) of six metacentric and four submetacentric pairs (numbers 2, 8, 9, and 10), while the American (Fig. 4B) showed six metacentric and four submetacentric-subtelocentric pairs (numbers 3, 7, 9, and 10). The position of the large submetacentric pair differed in the African (pair 2) and the American (pair 3) samples, as did a small submetacentric pair (pair 8 in the African samples and pair 7 in the American samples). But taking into account the confidence limits of the relative length means, pairs 2 and 3 of the African oyster may be confounded, as may pairs 7 and 8 (see Table 3 ). This means that these karyotypes are very similar overall. Furthermore, silver-stained NORs were located on the largest submetacentric chromosome pairs in both samples, and these most probably have the same position in the two karyotypes (Fig. 4, C and D).

\section{Discussion}

The molecular and karyological data reported here extend previous morphological, ecological, and allozyme studies on the taxonomic status and distribution of mangrove oysters from Africa and the east coast of South Africa. Our most striking and important result, however, is that one of the species occurs on both sides of the South Atlantic. This finding compels us to reassess the number of species of South American mangrove oysters, and to consider the mode and direction of the dispersal that must have led to this transoceanic distribution.

In the present study, all the African samples, initially identified as $C$. gasar, were found to be monomorphic for haplotype a, corresponding to sequence A. In contrast, 

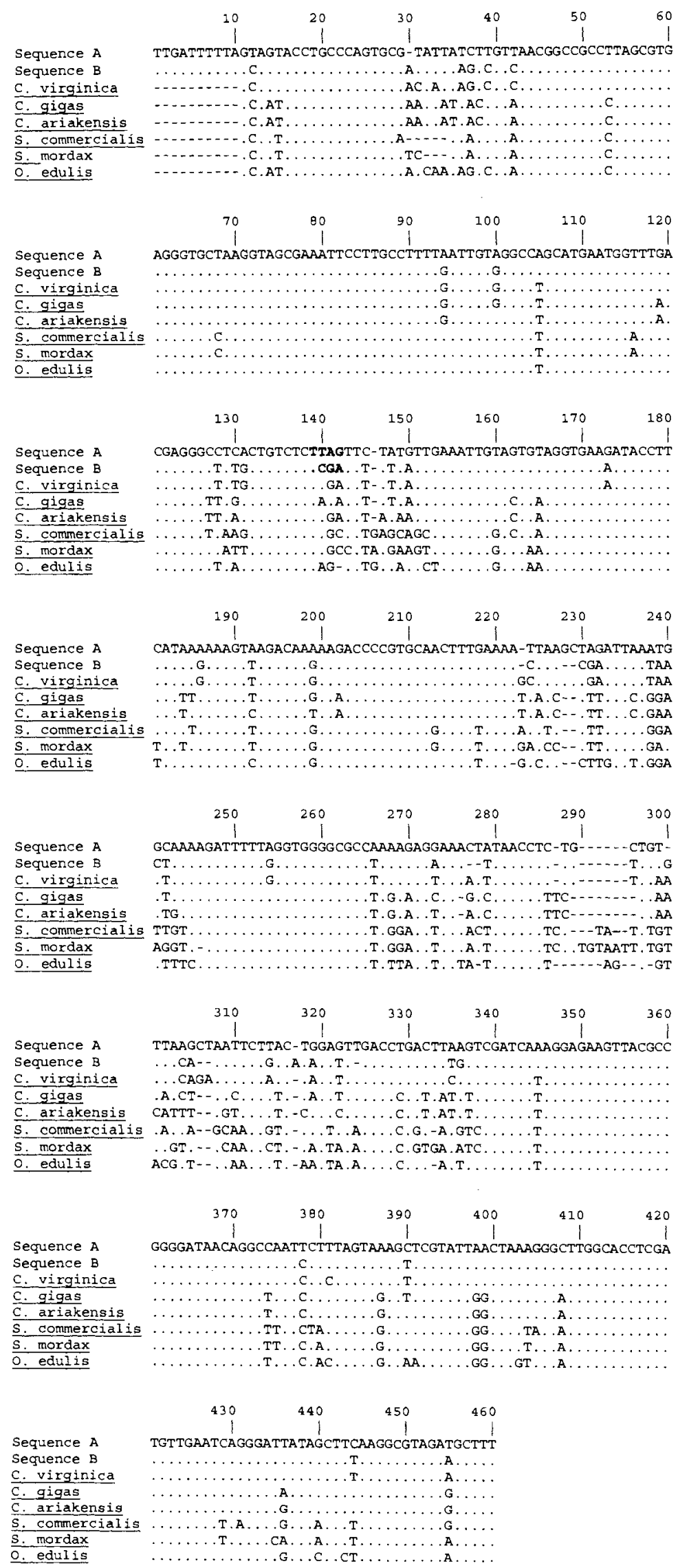

Figure 2. Alignment of the sequences $\mathrm{A}$ and $\mathrm{B}$, and of published sequences for Crassostrea virginica, $C$. gigas, and C. ariakensis (O'Foighil et al., 1995), Saccostrea commercialis, S. mordax (Lam and Morton, AF353100), and Ostrea edulis (Jozefowicz and O'Foighil, 1998). The four nucleotides in bold at position 141-144 correspond to a polymorphic restriction site for the TaqI enzyme. 


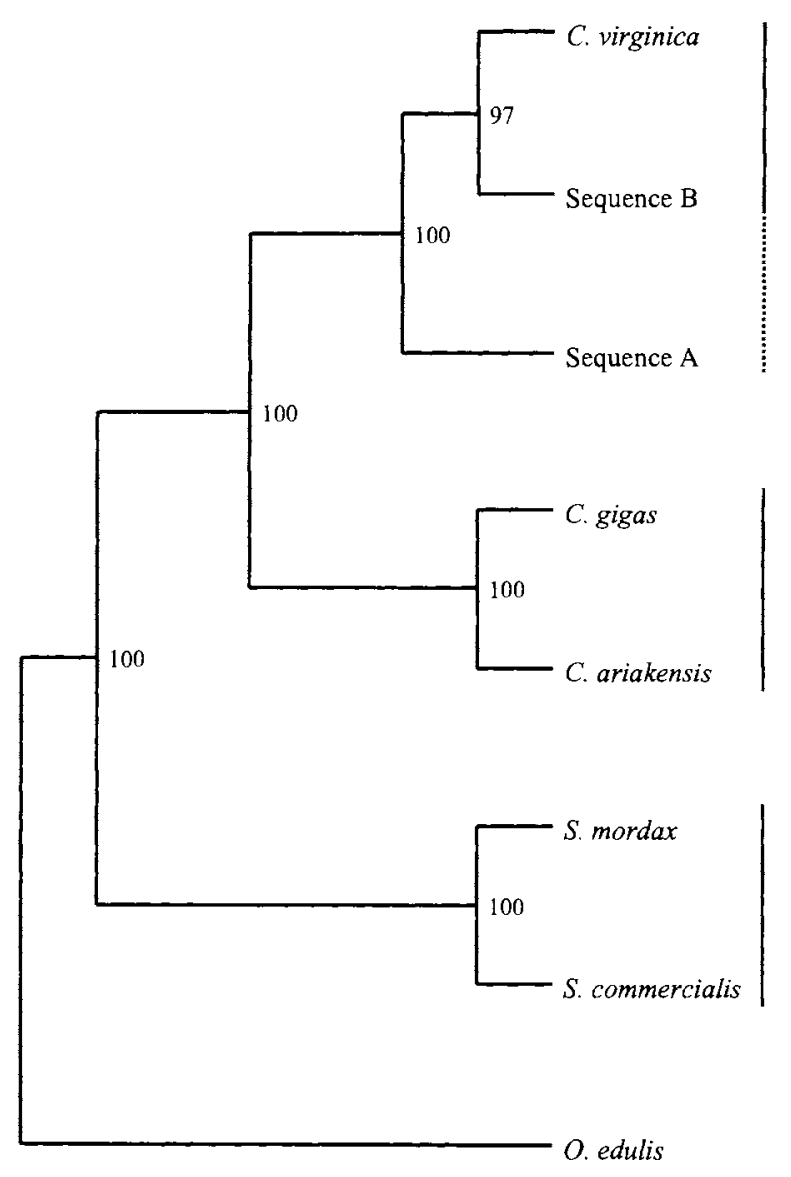

Figure 3. A phylogenetic tree based on a parsimony analysis of 480 nucleotide sequences of the $16 \mathrm{~S}$ gene according to Kimura's model (Kimura, 1980). Numbers on the branches indicate bootstrap values. Four groups of species were identified (1,2,3, and 4).

although almost all of the South American samples were first identified as $C$. rhizophorae, the $16 \mathrm{~S}$ sequence and RFLP analyses confirm the presence of at least two mangrove oyster species (haplotypes a and b, corresponding to sequences $\mathrm{A}$ and $\mathrm{B}$ ). That these two types can be considered as two different species is supported by the nucleotide divergence $(11 \%)$ between them, which is large when compared with the divergence calculated between $C$. gigas and C. ariakensis on the same fragment (5\%). On the basis of our results from the African samples, we propose that haplotype a and sequence A from along American coasts are attributable to the identified African species C. gasar. The other species present along the American coasts (sequence $\mathrm{B}$ and its corresponding PCR-RFLP haplotype $\mathrm{b}$ ) can be referred to as $C$. rhizophorae with more confidence. Hence, its close relationship with $C$. virginica ( $3.5 \%$ divergence) is strong evidence of its taxonomic status. The karyological observations support this species distribution. The karyotype of the French Guiana samples (presumed to be $C$. rhizophorae) showed six metacentric and four submetacentric-subtelocentric pairs. This picture is clearly different from the karyotypes previously described for C. rhizophorae; that is, five metacentric and five submetacentric pairs (Rodriguez-Romero et al., 1979; Ladron de Guevara et al., 1996) or eight metacentric and two submetacentric chromosomes (Marquez, 1992). However, when the French Guiana samples are compared with the African $C$. gasar samples, both karyotypes are very similar in the number and position of the metacentric and submetacentric pairs and the location of silver-stained NORs. The very slight differences in the centromere position of submetacentric-subtelocentric pairs in our American sample should not be taken as an interspecific chromosomal character, because karyotypes of cupped oysters differ in such characteristics (Leitão et al., 1999). Therefore, on the basis of our karyological observations, individuals from the French Guiana and Senegal samples are likely to be the same species, as was revealed by molecular analysis.

That populations separated by the Atlantic Ocean-and supposedly members of distinct species-are now revealed as being in the same species calls into question the actual number of species that occur on the eastern coast of South America. Recently, Ignacio et al. (2000) demonstrated, on the basis of allozyme data, that two distinct biological species, $C$. brasiliana and $C$. rhizophorae, occur along the coast of Brazil. To this short list, our study now adds $C$. gasar, which was found at three locations along the Atlantic coast of South America, one in French Guiana, and two in Brazil, in two bays $70 \mathrm{~km}$ apart. Now we must ask whether $C$. brasiliana and $C$. gasar are the same species. Unfortunately, a direct comparison between the $C$. brasiliana and $C$. gasar specimens could not be performed, but the question might be answered if we were to consider the interesting ecological preferences characterized by Ignacio et al. (2000). His specimens of $C$. rhizophorae oysters were small and attached in the intertidal zone, either to mangrove (Rhizophorae mangle) roots, or to rocks in the intertidal zone. Conversely, C. brasiliana oysters were larger and attached to rocks in the subtidal zone. In comparison, $C$. rhizophorae typically settles on the mangrove roots, but occasionally also on rocks (Nascimento et al., 1991; Rios, 1994). Finally, in Nigeria (Africa), C. gasar favors the subtidal zone, although it can, in the dry season, occur a little above the level of low tide (Ajana, 1980). These preferences do not resolve species relationships, and in our South American study, we could not correlate either the size of the oysters or their habitat with their taxonomic status.

Our genetic study, based on the mitochondrial and nuclear genomes, clearly demonstrates that a common mangrove species is present in South America and Africa. But did this species originate in South America or Africa? And when, and by what means, did the dispersal occur? The identical mtDNA sequences of American and African $C$. gasar oysters show that these two population groups have a 
TRANS-ATLANTIC DISTRIBUTION OF A MANGROVE OYSTER

Table 3

Chromosome measurements derived from 10 cells of each sample

\begin{tabular}{|c|c|c|c|c|c|c|c|c|c|}
\hline Chrom. pair no. & Mean RL & Conf. L. & RL $\max$ & $\mathrm{RL}, \mathrm{min}$ & Mean $\mathrm{Cl}$ & Conf. L. & $\mathrm{CI} \max$ & $\mathrm{CI}$ min & Type* \\
\hline \multicolumn{10}{|c|}{ NOB sample: putative Crassostrea gasar } \\
\hline 1 & 11.36 & 0.48 & 11.84 & 10.89 & 43.64 & 2.34 & 45.99 & 41.30 & $\mathrm{~m}$ \\
\hline 2 & 11.19 & 0.53 & 11.72 & 10.67 & 27.52 & 1.67 & 29.19 & 25.84 & $\sin$ \\
\hline 3 & 11.04 & 0.29 & 11.33 & 10.75 & 45.62 & 1.77 & 47.39 & 43.85 & $\mathrm{~m}$ \\
\hline 4 & 10.62 & 0.54 & 11.16 & 10.08 & 37.80 & 1.65 & 39.45 & 36.14 & $\mathrm{~m} / \mathrm{sm}$ \\
\hline 5 & 10.54 & 0.36 & 10.90 & 10.18 & 46.95 & 1.75 & 48.70 & 45.20 & $\mathrm{~m}$ \\
\hline 6 & 9.97 & 0.31 & 10.28 & 9.66 & 45.77 & 1.66 & 47.43 & 44.10 & $\mathrm{~m}$ \\
\hline 7 & 9.64 & 0.39 & 10.03 & 9.25 & 45.21 & 2.53 & 47.75 & 42.68 & $\mathrm{~m}$ \\
\hline 8 & 9.54 & 0.45 & 9.99 & 9.08 & 30.78 & 2.45 & 33.23 & 28.33 & $\mathrm{sm}$ \\
\hline 9 & 8.82 & 0.43 & 9.25 & 8.39 & 28.65 & 2.15 & 30.80 & 26.49 & $\mathrm{sm}$ \\
\hline 10 & 7.28 & 0.40 & 7.68 & 6.88 & 27.89 & 2.70 & 30.59 & 25.19 & $\mathrm{sm}$ \\
\hline \multicolumn{10}{|c|}{ SIN sample: putative Crassostrea rhizophorae } \\
\hline 1 & 12.08 & 0.40 & 12.48 & 11.68 & 44.51 & 1.76 & 46.26 & 42.75 & $\mathrm{~m}$ \\
\hline 2 & 11.83 & 0.48 & 12.31 & 11.35 & 42.57 & 2.52 & 45.09 & 40.05 & $\mathrm{~m}$ \\
\hline 3 & 10.86 & 0.36 & 11.22 & 10.50 & 26.02 & 2.37 & 28.39 & 23.66 & $\mathrm{sm} / \mathrm{st}$ \\
\hline 4 & 10.73 & 0.41 & 11.15 & 10.32 & 44.15 & 2.95 & 47.10 & 41.21 & $\mathrm{~m}$ \\
\hline 5 & 10.58 & 0.60 & 11.18 & 9.98 & 37.00 & 2.22 & 39.22 & 34.78 & $\mathrm{~m} / \mathrm{sm}$ \\
\hline 6 & 9.87 & 0.29 & 10.16 & 9.58 & 42.65 & 2.16 & 44.81 & 40.50 & $\mathrm{~m}$ \\
\hline 7 & 9.76 & 0.42 & 10.18 & 9.33 & 24.98 & 1.35 & 26.33 & 23.63 & $\mathrm{sm} / \mathrm{st}$ \\
\hline 8 & 9.15 & 0.56 & 9.71 & 8.59 & 43.57 & 1.39 & 44.96 & 42.19 & $\mathrm{~m}$ \\
\hline 9 & 8.76 & 0.27 & 9.04 & 8.49 & 24.29 & 1.00 & 25.29 & 23.29 & $\mathrm{sm} / \mathrm{st}$ \\
\hline 10 & 6.37 & 0.53 & 6.90 & 5.84 & 26.07 & 2.23 & 28.30 & 23.85 & $\mathrm{sm} / \mathrm{st}$ \\
\hline
\end{tabular}

Cl: centromeric index, Conf. L.: confidence limit of means, RL: relative length, m: metacentric, sm: submetacentric, st: subtelocentric. The boldface values correspond to the confidence limits of the relative length means of chromosome pairs that allow pairs 2 and 3 to be confounded, and likewise pairs 7 and 8 .

* The morphological type of chromosome is given according to the $\mathrm{CI}$ max and $\mathrm{CI} \mathrm{min}$; $\mathrm{m} / \mathrm{sm}$ means that the type of the chromosome pair is on the edge of the two classes-metacentric and submetacentric (see classification in Levan et al., 1964).

relatively recent common origin. O'Foighil et al. (1998) analyzed sequences of the cytochrome oxidase I gene and dated the genetic divergence between $C$. gigas and $C$. angulata at 1 to 2 million years. When the $16 \mathrm{~S}$ ribosomal gene was analyzed, the divergence between the two taxa was estimated to be $0.46 \%$ (Huvet, 2000; unpubl. data provided by $O^{\prime}$ Foighil). If we assume that mutation rates at the cytochrome oxidase I gene are similar among Crassostrea species, then the African and American populations of $C$. gasar were established less than 1 to 2 million years ago. To assess the level of polymorphism of the $16 \mathrm{~S}$ ribosomal gene in C. gasar, a larger sample size would be necessary. For example, Small and Chapman (1997) used a PCR-RFLP approach (10 restriction enzymes) on 410 individuals from the Atlantic coasts and the Gulf of Mexico to study intraspecific variation in the $16 \mathrm{~S}$ ribosomal gene of $C$. virginica. They found 11 haplotypes, of which one was highly frequent $(95 \%)$. Thus, the level of genetic divergence between the American and African C. gasar populations could probably be better estimated if more polymorphic markers were available.

The relatively recent divergence between the American and African populations of C. gasar supports the hypothesis that man was an agent of the dispersal. Many recent transfers and worldwide introductions of oysters for aquacultural purposes have been reported (Carlton and Mann, 1996). Furthermore, events of introduction in historic time have been demonstrated on the basis of genetic markers (O'Foighil et al., 1998; Boudry et al., 1998). In the case of C. gasar, shipping between South America and the west coast of Africa may have transferred these oysters from one coast to the other. Note, however, that no C. rhizophorae samples were found in Senegal or Nigeria. Although the west African coast must be more extensively sampled to confirm this result, it does imply that, unlike C. gasar, C. rhizophorae either was not transported to or did not persist on the African coast.

Natural transport may also be responsible for the present geographic range of $C$. gasar. Larval dispersal might have been possible, even over such a long distance (at least 3000 $\mathrm{km}$ ), because the larval stage of most Crassostrea species lasts about 3 weeks. However, the transport of adult oysters on drifting objects, a common phenomenon in the marine environment, may be a mode of dispersal with a larger potential range than that achievable by swimming larvae (Johannesson, 1988; O'Foighil, 1989). For example, dis- 


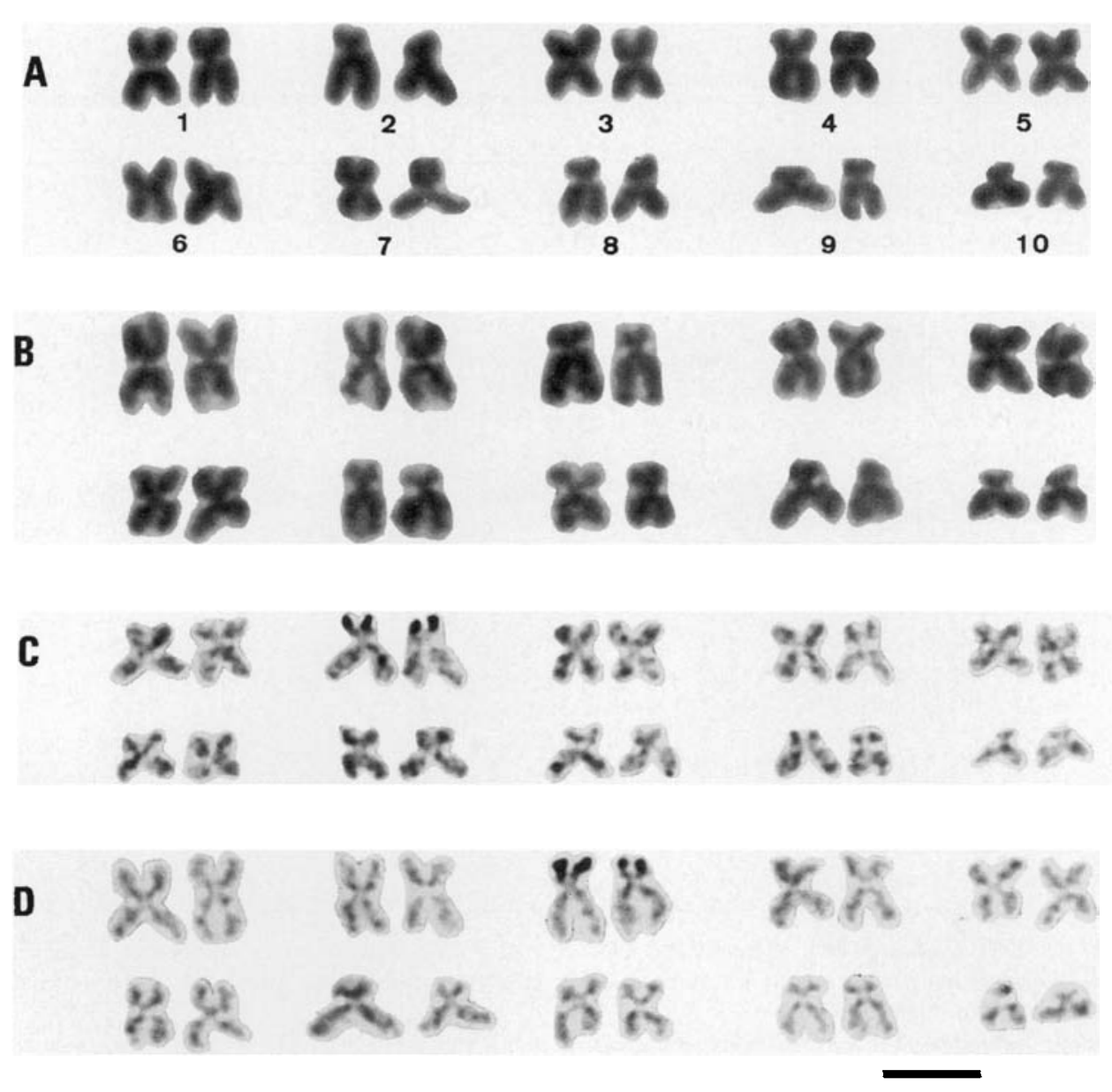

Figure 4. (A) Giemsa-stained karyotype of African Crassostrea gasar, (B) Giemsa-stained karyotype of putative $C$. rhizophorae from French Guiana, (C) NOR-stained karyotype of African $C$. gasar, (D) NOR-stained karyotype of putative $C$. rhizophorae from French Guiana. Scale bar $=5 \mu \mathrm{m}$.

persal by rafting was the most likely explanation for transPacific range extension by the flat oyster Ostrea chilensis from New Zealand to Chile (O'Foighil et al., 1999). The predominant surface circulation patterns in this part of the Atlantic Ocean (Fig. 1) favor the hypothesis that C. gasar was transported from Africa to America, as also hypothesized by Lessios et al. (1999) to explain the close genetic similarity of specimens of Eucidaris tribuloides from the Caribbean Sea and Brazil to those from the Gulf of Guinea.

Focusing on the Paraguana Bay (Brazil) where two species were found, PAR1 exhibited the $C$. gasar haplotype, but PAR2 and PAR3, both located in the same bay about 30 $\mathrm{km}$ away, exhibited the $C$. rhizophorae haplotype. One can ask whether these species are completely or incompletely reproductively isolated, and whether they have different habitats. A more intensive survey could provide an answer by revealing whether individuals from these species inhabit the same site, and whether hybrids occur in the wild. Based on the rRNA large subunit DNA sequences, and those known between other species in the genus (see Table 2), the genetic distance between $C$. gasar and $C$. rhizophorae is sufficiently large ( $88.7 \%$ similarity) that they are unlikely to produce viable hybrids. Indeed, the genetic distance between $C$. gigas and $C$. virginica, two species for which viable hybrids could not be obtained (Allen et al., 1993), is of similar value ( $84.5 \%$ similarity).

\section{Acknowledgments}

We thank M. Antonio, F. Blouin, F. Cornette, W.B. Dambo, H.D. Diadhiou, P. Favrenière, N. Jan, P. Noble, P. Phelipot, Y. Pichot, A. Pinheiro, J.-L. Seugnet, and A. Thébault for providing oyster samples; B. Verdon for technical help; and L. Petit de la Villeon for his research on surface circulation patterns in the South Atlantic. Part of this work was supported by the Région Poitou-Charentes (Convention 99 RPC-A-201). We are grateful to D. Moraga, A. Tanguy, D. O'Foighil, and another anonymous reviewer for their help in improving the manuscript, as well as to $\mathrm{H}$. McCombie for English editing. 


\section{Literature Cited}

Absher, T. M. 1989. Populações naturais de ostras do gênero Crassostrea do litoral do Paraná-desenvoltimento larval, recrutamento e crescimento. Ph.D. thesis. Oceanography Institute, Universadade de São Paulo, São Paulo, Brazil.

Ajana, A. M. 1979. Preliminary investigation into some factors affecting the settlement of the larvae of the mangrove oyster Crassostrea gasar (Adanson) in the Lagos lagoon. Malacologia 18: 271-275.

Ajana, A. M. 1980. Fishery of the mangrove oyster, Crassostrea gasar, Adanson (1757), in the Lagos area, Nigeria. Aquaculture 21: 129-137.

Akpagana, K. 1993. L'écosystème des mangroves et des formations affiliées du Sud-Est du Togo. Pp. 108-119 in Conservation et utilisation rationnelle des forêts de Mangrove de l'Amérique latine et de l'Afrique, Vol. 2. E. S. Diop, ed. UNESCO-COMAR, Paris.

Allen, S. K., Jr., P. M. Gaffney, J. Scarpa, and D. Bushek. 1993. Inviable hybrids of Crassostrea virginica (Gmelin) with $C$. rivularis (Gould) and C. gigas (Thunberg). Aquaculture 113: 269-289.

Arakawa, K. Y. 1990. Commercially important species of oysters in the world. Mar. Behav. Physiol. 17: 1-13.

Banks, M. A., D. Hedgecock, and C. Waters. 1993. Discrimination between closely related Pacific oyster species (Crassostrea) via mitochondrial DNA sequences coding for large subunit rRNA. Mol. Mar. Biol. Biotechnol. 2: 129-136.

Blasco, F., T. Gauquelin, M. Rasolofoharinoro, J. Denis, M. Aizpuru, and V. Caldairou. 1998. Recent advances in mangrove studies using remote sensing data. Mar. Freshw. Res. 49: 287-296.

Boudry, P., S. Heurtebise, B. Collet, F. Cornette, and A. Gérard. 1998. Differentiation between populations of the Portuguese oyster, Crassostrea angulata (Lamarck) and the Pacific oyster, Crassostrea gigas (Thunberg), revealed by mtDNA RFLP analysis. J. Exp. Mar. Biol. Ecol. 226: 279-291.

Carlton, J. T., and R. Mann. 1996. Transfers and world-wide introductions. Pp. 691-706 in The Eastern Oyster Crassostrea virginica, V.S Kennedy, R.I.E. Newell, and A.F. Eble, eds. Maryland Sea Grant, College Park, MD.

Cormier-Salem, M. C. 1987. La cueillette des huîtres en Casamance. Place de cette pratique dans le système d'exploitation Diola. Document scientifique du Centre de recherche océanographiques de DakarTiaroye 106: $104 \mathrm{pp}$.

Day, A. J., A. J. S. Hawkins, and P. Visootiviseth. 2000. The use of allozymes and shell morphology to distinguish among sympatric species of the rock oyster Saccostrea in Thailand. Aquaculture 187: 51-72.

Diop, E. S. 1993. Les mangroves du Sénégal et de la Gambie. Pp. 22-40 in Conservation et utilisation rationnelle des forêts de Mangrove de l'Amérique latine et de l'Afrique, Vol. 2. E. S. Diop, ed. UNESCOCOMAR, Paris.

Egnankou, M. W. 1993. Les mangroves de Côte d'Ivoire. Pp. 83-93 in Conservation et utilisation rationnelle des forêts de Mangrove de l'Amérique latine et de l'Afrique, Vol. 2. E. S. Diop, ed. UNESCOCOMAR, Paris.

Estoup, A., C. R. Largiader, E. Perrot, and D. Chourrout. 1996. Rapid one-tube DNA extraction for reliable PCR detection of fish polymorphic markers and transgenes. Mol. Mar. Biol. Biotechnol. 5: 295-298.

Felsenstein, J. 1989. PHYLIP_-Phylogeny Inference Package (Version 3.2). Cladistics 5: 164-166.

FAO. 1999. Aquaculture Production Statistics, 1988-1997. FAO Fishery Circular 815, Revision 11, p. 82, Food and Agriculture Organization of the United Nations, Rome.

Galtsoff, P. S. 1964. The American oyster Crassostrea virginica Gmelin. U.S. Fish and Wildl. Serv. Fish. Bull. 64: 479 pp.

Gowthorpe, P. 1993. Les mangroves de la Mauritanie. Pp. 3-21 in Conservation et utilisation rationnelle des forêts de Mangrove de
l'Amérique latine et de l'Afrique; Vol. 2. E. S. Diop, ed. UNESCOCOMAR, Paris.

Hedgecock, D., and N. B. Okazaki. 1984. Genetic diversity within and between populations of American oysters (Crassostrea). Malacologia 25: 535-549.

Hedgecock, D., G. Li, M. A. Banks, and Z. Kain. 1999. Occurrence of the Kumamoto oyster Crassostrea sikamea in the Ariake Sea, Japan. Mar. Biol. 133: 65-68.

Howell, W. M., and D. A. Black. 1982. Controlled silver-staining of nucleolus organizer regions with a protective colloidal developer: a 1-step method. Experientia 36: 1014- 1015.

Huvet, A. 2000. Ressources génétiques et phylogéographie des huîtres creuses Crassostrea gigas et $C$. angulata: variabilité, différenciation et adaptation des populations naturelles et introduites. Ph.D. thesis. Université de Tours, France. 202 pp.

Ignacio, B. L., T. M. Absher, C. Lazoski, and A. M. Solé-Cava. 2000. Genetic evidence of the presence of two species of Crassostrea (Bivalvia: Ostreidae) on the coast of Brazil. Mar. Biol. 136: 987-991.

Isebor, C. E., and L. F. Et Awosika. 1993. Les ressources de la mangrove au Nigeria: son état et sa mise en valeur. Pp. 169-188 in Conservation et utilisation rationnelle des forêts de Mangrove de l'Amérique latine et de l'Afrique; Vol. 2. E. S. Diop, ed. UNESCOCOMAR, Paris.

Johannesson, K. 1988. The paradox of Rockall: Why is a brooding gastropod (Littorina saxatilis) more widespread than one having a planktonic larval stage (L. littorea)? Mar. Biol. 99: 507-513.

Jozefowicz, C. J., and D. O. O'Foighil. 1998. Phylogenetic analysis of southern hemisphere flat oysters based on partial mitochondrial $16 \mathrm{~S}$ rDNA gene sequences. Mol. Phylogenet. Evol. 10: 426-435.

Kamara, A. B. 1982. Preliminary studies to culture mangrove oysters, Crassostrea tulipa, in Sierra Leone. Aquaculture 27: 285-294.

Kimura, M. 1980. A simple method for estimating evolutionary rates of base substitutions through comparative studies of nucleotide sequences. J. Mol. Evol. 16: 111-120.

Ladron de Guevara, B., F. Winkler, F. Rodriguez-Romero, and C. Palma-Rojas. 1996. Comparative karyology of four American oyster species. Veliger 39: 260-266.

Lawrence, D. R. 1995. Diagnosis of the genus Crassostrea (Bivalvia, Ostreidae). Malacologia 36: 185-202.

Leitão, A., P. Boudry, J.-P. Labat, and C. Thiriot-Quiévreux. 1999. Comparative karyological study of cupped oyster species. Malacologia 41: $175-186$

Lessios, H. A., B. D. Kessing, D. R. Robertson, and G. Paulay. 1999. Phylogeography of the pantropical sea urchin Eucidaris in relation to land barriers and ocean currents. Evolution 53: 806-817.

Levan, A., K. Fredga, and A. A. Sandberg. 1964. Nomenclature for centromere position in chromosomes. Hereditas 52: 201-220.

Littlewood, D. T. 1991. Oyster cultivation in the Caribbean with an emphasis on mangrove oysters in Jamaica. World Aquacult. 22: 70-73.

Littlewood, D. T. 1994. Molecular phylogenetics of cupped oysters based on partial 28S rRNA gene sequences. Mol. Phylogenet. Evol. 3: 221-229.

Makaya, J.-F. 1993. La mangrove au Congo: son état actuel. Pp. $208-$ 213 in Conservation et utilisation rationnelle des forêts de Mangrove de l'Amérique latine et de l'Afrique, Vol. 2. E. S. Diop, ed. UNESCOCOMAR, Paris.

Marozova, A. L., K. D. Leung-Tack, V. I. Kholodov, V. V. Trousevich, S. Camara, V. K. Maskevski, F. X. Ibrahimov, and P. D. Lamakin. 1991. L'ostréiculture en milieux de mangroves (Etude de cas en Guinée et au Sénégal), I.E. Timchenko and S. Konate, eds. Série documentaire 7, COMAR, France, $148 \mathrm{pp}$.

Marquez, E. G. 1992. Comparación de cariotipos entre las ostras Crassostrea virginica (Gmelin), C. rhizophorae (Guilding) y Pinctada imbricata (Röding). Caribb. J. Sci. 28: 51-55. 
Moore, D. 1993. Preparation of genomic DNA from mammalian tissue. Pp. 1-2 in Current Protocols in Molecular Biology, Vol. 1, F.M. Ausubel, ed. John Wiley, New York.

Nakamura, H. 1985. A review of molluscan cytogenetic information based on CISMOCH-Computerized index system for molluscan chromosomes. Bivalvia, Polyplacophora and Cephalopoda. Venus Jpn. J. Malacol. 44: 193-225.

Nascimento, I. A. 1991. Crassostrea rhizophorae (Guilding) and $C$. brasiliana (Lamarck) in South and Central America. Pp. 125-134 in Estuarine and Marine Bivalve Mollusk Culture, W. Menzel, ed. CRC Press, Boca Raton, FL.

Nicklès, M. 1950. Mollusques testaces marins de la côte occidentale d'Afrique, Manuels Ouest-Africains 2: 1-269.

O'Foighil, D. 1989. Planktotrophic larval development is associated with a restricted geographic range in Lasea, a genus of brooding, hermaphrodite bivalves. Mar. Biol. 103: 349-358.

O'Foighil, D., and D. J. Taylor. 2000. Evolution of parental care and ovulation behavior in oysters. Mol. Phylogenet. Evol. 15: 301-313.

O'Foighil, D., P. Gaffney, and T. J. Hilbish. 1995. Differences in mitochondrial 16S ribosomal gene sequences allow discrimination among American [Crassostrea virginica (Gmelin)] and Asian [C. gigas (Thunberg) C. ariakensis (Wakiya)] oyster species. J. Exp. Mar. Biol. Ecol. 192: 211-220.

O'Foighil, D., P. Gaffney, A. E. Wilbur, and T. J. Hilbish. 1998. Mitochondrial cytochrome oxidase I gene sequences support an Asian origin for the Portuguese oyster Crassostrea angulata. Mar. Biol. 131: 497-503.

O'Foighil, D., B. A. Marshall, T. J. Hilbish, and M. A. Pino. 1999. Trans-Pacific range extension by rafting is inferred for the flat oyster Ostrea chilensis. Biol. Bull. 196: 122-126.

Rios, E. C. 1994. Seashells of Brazil. Fundaçao Universidade do Rio Grande, Rio Grande, Brazil.

Rodriguez-Romero, F., M. Uribe-Alcocer, A. Laguarda-Figueras, and M. E. Diopotex-Chong. 1979. The karyotype of Crassostrea rhizophorae (Guilding). Venus Jpn. J. Malacol. 38: 135-140.

Small, M. P., and R. W. Chapman. 1997. Intraspecific variation in the 16S ribosomal gene of Crassostrea virginica. Mol. Biol. Biotechnol. 3: 189-196.

Thiriot-Quiévreux, C., and N. Ayraud. 1982. Les caryotypes de quelques espèces de Bivalves et de Gastéropodes marins. Mar. Biol. 70: $165-172$.

Thompson, J. D., D. G. Higgins, and T. J. Gibson. 1994. CLUSTAL W: improving the sensitivity of progressive multiple sequence alignment through sequence weighting, position-specific gap penalties and weight matrix choice. Nucleic Acids Res. 22: 4673- 4680.

Yoo, S. K., and H. K. Ryu. 1984. Comparative morphological characteristics of mangrove oysters. Bull. Korean Fish. Soc. 174: 321-326.

Zogning, A. 1993. Les mangroves du Cameroun. Pp. 189-196 in Conservation et utilisation rationnelle des forêts de Mangrove de l'Amérique latine et de l'Afrique, Vol. 2. E. S. Diop, ed. UNESCOCOMAR, Paris. 
http://www.jstor.org

\section{LINKED CITATIONS \\ - Page 1 of 1 -}

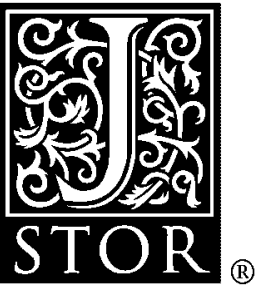

You have printed the following article:

Trans-Atlantic Distribution of a Mangrove Oyster Species Revealed by 16S mtDNA and Karyological Analyses

S. Lapègue; I. Boutet; A. Leitão; S. Heurtebise; P. Garcia; C. Thiriot-Quiévreux; P. Boudry

Biological Bulletin, Vol. 202, No. 3. (Jun., 2002), pp. 232-242.

Stable URL:

http://links.jstor.org/sici?sici=0006-3185\%28200206\%29202\%3A3\%3C232\%3ATDOAMO\%3E2.0.CO\%3B2-5

This article references the following linked citations. If you are trying to access articles from an off-campus location, you may be required to first logon via your library web site to access JSTOR. Please visit your library's website or contact a librarian to learn about options for remote access to JSTOR.

\section{Literature Cited}

Phylogeography of the Pantropical Sea Urchin Eucidaris in Relation to Land Barriers and Ocean Currents

H. A. Lessios; B. D. Kessing; D. R. Robertson; G. Paulay

Evolution, Vol. 53, No. 3. (Jun., 1999), pp. 806-817.

Stable URL:

http://links.jstor.org/sici?sici=0014-3820\%28199906\%2953\%3A3\%3C806\%3APOTPSU\%3E2.0.CO\%3B2-1

Trans-Pacific Range Extension by Rafting Is Inferred for the Flat Oyster Ostrea chilensis

Diarmaid Ó. Foighil; Bruce A. Marshall; Thomas J. Hilbish; Mario A. Pino

Biological Bulletin, Vol. 196, No. 2. (Apr., 1999), pp. 122-126.

Stable URL:

http://links.jstor.org/sici?sici=0006-3185\%28199904\%29196\%3A2\%3C122\%3ATREBRI\%3E2.0.CO\%3B2-V 